\title{
Outcome of Surgical Treatment of Stress Fracture Neck of Femur in Military Recruits
}

\author{
Sushil Rana Magar, Pankaj Chand, Bishnu Babu Thapa, Ritesh Sinha, Rajesh Pratap Shah, \\ Dipendra Maharjan and Sushil Shrestha
}

Department of Orthopaedics, Nepalese Army Institute of Health Sciences, Shree Birendra Hospital, Chhauni, Kathmandu, Nepal

\begin{abstract}
Introduction: Stress fracture of neck of femur is known to occur in athletes and soldiers. From treatment perspective, this is still an unsolved fracture. The purpose of this study is to critically analyse the functional outcome of surgical treatment of stress fracture of neck of femur in military recruits performed by the same surgical team.

Methods: This is a retrospective study of surgically treated femoral neck stress fracture from $1^{\text {st }}$ December 2012 to $1^{\text {st }}$ December 2013. All fractures were fixed with three $6.5 \mathrm{~mm}$ cancellous lag screws with washers. For failure of primary fixation or non-union, osteosynthesis with fibular strut graft was performed. Patients were evaluated at six weeks, 12 weeks, six months, 12 months and then yearly for three years. Functional outcome was evaluated by using Harris Hip Score at six months and at final follow-up. The outcome was followed up for six years up to Dec 2019.

Results: There were eight males and one female patient. Mean age of patient was 20.7 years (Range, 19-23 years). Average follow-up period was 67.6 months (range 6-81). Lag screw fixation was done in five cases after closed reduction and in four cases after open reduction. Osteosynthesis with fibular graft was done in two cases. In six cases, fracture united at a mean duration of 9.8 months (Range 6-20). In three cases there was non-union of the fracture with added infection in one case. Avascular necrosis of femoral head developed in two cases.
\end{abstract}

Conclusions: Successful surgical treatment of stress fracture of neck of femur requires anatomical reduction and stable interfragmentary compression with lag screws.

Key words: avascular necrosis; cancellous lag screw; fibular strut graft; interfragmentary compression; osteosynthesis

Correspondence: Sushil Rana Magar, Department of Orthopaedics, Nepalese Army Institute of Health Sciences, Shree Birendra Hospital, Kathmandu, Nepal. E-mail: sushilrana538@gmail.com

DOI: http://dx.doi.org/10.3126/mjsbh.v19i2.28278

Submitted on: $2020-03-30$

Accepted on: 2020-04-14

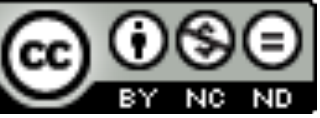

This work is licensed under creative common license:

http://creativecommons.org/licenses/by-nc-nd/4.0/ (C) MJSBH 2020 


\section{INTRODUCTION}

Stress fracture is a well-recognised medical condition first described by Breithaupt in 1885 in Prussian military recruits. ${ }^{1}$ Stress fracture is defined as the injury resulting from repetitive mechanical stress in a normal bone in an otherwise healthy individual. It generally involves tibial shaft, especially in runners and joggers who run long on hard surfaces like roads.

Stress fracture of neck of femur is a rare condition in general population. However, it is common in athletes and military recruits due to the physical stresses exerted upon them during training. ${ }^{2}$ Fullerton and Snowdy classified femoral neck stress fracture (FNSF) into three types: type Atension type, type B- compression type and type Cdisplaced type. ${ }^{3}$ Displaced FNSF is a dreaded condition as it is associated with higher incidence of non-union and avascular necrosis of the femoral head. ${ }^{3,4}$ Tension type fracture and displaced FNSF require surgical fixation whereas compression type fracture can be managed conservatively. ${ }^{5,6}$

The surgical treatment options for FNSF are in-situ fixation with Cannulated Cancellous Screw (CCS), closed reduction and internal fixation with CCS or Dynamic Hip Screw (DHS), open reduction and internal fixation with CCS or DHS, open reduction and internal fixation with vascularised fibular graft or non-vascular fibular strut graft or muscle pedicle bone graft. ${ }^{5-8}$ There is paucity of studies on surgical treatment of FNSF in Nepalese population published in the literature.

The purpose of this study is to critically analyse the functional outcome of surgical treatment of femoral neck stress fracture in military recruits performed by the same surgical team over a period of one year in a tertiary care referral central hospital in Kathmandu, Nepal.

\section{METHODS}

This is a retrospective record based observational study of all military recruits with femoral neck stress fracture (FNSF) treated with surgical intervention in a tertiary care referral centre of Nepalese Army, located in Kathmandu, Nepal over a one year period $\left(1^{\text {st }}\right.$ December 2012 to $1^{\text {st }}$ December 2013). Ethical clearance for the study was taken from the Institutional Review Committee
(IRC) of our institute. The outcome was followed up for six years up to Dec 2019.

Indication for in-situ fixation with $\mathrm{CCS}$ was Fullerton and Snowdy type B fracture. Indication for closed reduction and internal fixation with CCS was Fullerton and Snowdy type A or type C fracture with acceptable alignment after closed reduction. Indication for open reduction was failure of closed reduction.

Surgical treatment was done by the the same surgical team under spinal anaesthesia. Using strict aseptic precautions, part was prepared and draped and patient was placed in supine position on a fracture table. Closed reduction of displaced fracture neck of femur was performed with longitudinal traction of the limb in external rotation of the leg, followed by abduction up to $20^{\circ}$ and finally $20^{\circ}-30^{\circ}$ internal rotation of the leg as described by Whitman. ${ }^{5}$ Acceptability of the reduction was assessed with the help of portable Xray AP (Antero-posterior) and lateral view using Garden's Alignment Index. ${ }^{9}$ Three $6.5 \mathrm{~mm}$ CCS with washers were used to fix the fracture in a reverse triangle configuration in all cases. For failure of closed reduction, open reduction was performed using Watson-Jones approach. ${ }^{10}$ In cases with failure of primary fixation or non-union of fracture, osteosynthesis with fibular strut graft and one $6.5 \mathrm{~mm}$ cancellous screw as described by Nagi et al. was performed. ${ }^{11}$

Strict post-operative rehabilitation protocol was followed for all patients. For internal fixation with CCS, touch-down non-weight bearing ambulation with axillary crutches for six weeks was allowed. It was followed by gradual weight bearing ambulation as tolerated depending upon the clinical and radiological signs of healing. For osteosynthesis with fibular strut graft and a cancellous screw, touch-down non-weight bearing ambulation with axillary crutches and a long knee brace was continued for 12 weeks.

Follow-up evaluation was done using check X-ray pelvis with both hips-AP view and X-ray of the affected hip-lateral view. Patients were further evaluated with X-rays at six weeks, 12 weeks, six months, 12 months and then yearly for three years. Harris Hip Score (HHS) was evaluated at six months and at final follow-up. ${ }^{11}$ Complications and residual symptoms were also evaluated. For 
symptomatic patients, MRI was performed to rule out avascular necrosis (AVN) of femoral head. Data analysis was performed with IBM SPSS version 21

\section{RESULTS}

There were eight males and a female patient. The mean age of the patient was 20.7 years (Range, 19 23 years). Average follow-up period was 67.6 months (Range 6 - 81 months). Right side was involved in six patients and left side was involved in three patients. Eight cases had Fullerton and
Snowdy type C fracture (displaced) and one case had type A fracture (undisplaced tension type).

All military recruits sustained FNSF at mean duration of training of 6.3 months (Range, 4 - 10). Closed reduction and lag screw fixation were done in five cases out of which one case $(20 \%)$ had failure of primary fixation. For this case, revision surgery with open reduction and fibular strut grafting was performed after four months. At nine months of follow-up, there was non-union with broken CCS and fibular graft.

Table 1. Demographic data with details of patients

\begin{tabular}{|c|c|c|c|c|c|c|c|c|c|c|c|c|}
\hline $\begin{array}{l}\text { Case } \\
\text { No. }\end{array}$ & Age & Sex & Side & Type & $\begin{array}{l}\text { Method } \\
\text { of } \\
\text { reduction }\end{array}$ & $\begin{array}{l}\text { Duration } \\
\text { of } \\
\text { training }\end{array}$ & $\begin{array}{l}\text { Onset } \\
\text { of } \\
\text { pain } \\
\text { before } \\
\text { FNSF } \\
\end{array}$ & $\begin{array}{l}\text { Time delay } \\
\text { between } \\
\text { presentation } \\
\& \text { surgery }\end{array}$ & $\begin{array}{l}\text { Union } \\
\text { time in } \\
\text { month }\end{array}$ & $\begin{array}{l}\text { Additional } \\
\text { Surgery }\end{array}$ & $\begin{array}{l}\text { Complications } \\
\text { at final follow- } \\
\text { up }\end{array}$ & $\begin{array}{l}\text { Follow- } \\
\text { up } \\
\text { duration } \\
\text { in } \\
\text { months }\end{array}$ \\
\hline 1 & 23 & $\mathrm{M}$ & Rt. & $\mathrm{C}$ & CR & $\begin{array}{l}10 \\
\text { months }\end{array}$ & 4 days & $48 \mathrm{hrs}$ & 6 & None & None & 81 \\
\hline 2 & 19 & M & Rt. & $\mathrm{C}$ & $\mathrm{CR}$ & $\begin{array}{l}6 \\
\text { months }\end{array}$ & $\begin{array}{l}10 \\
\text { days }\end{array}$ & $72 \mathrm{hrs}$ & $\begin{array}{l}\text { Non- } \\
\text { union }\end{array}$ & $\begin{array}{l}\text { Open reduction } \\
\text { and fibular strut } \\
\text { grafting after } 4 \\
\text { months of } \\
\text { index surgery }\end{array}$ & $\begin{array}{l}\text { Non-union with } \\
\text { broken CCS } \\
\text { after } 9 \text { months }\end{array}$ & 80 \\
\hline 3 & 19 & M & Lt. & $\mathrm{C}$ & $\mathrm{CR}$ & $\begin{array}{l}7 \\
\text { months }\end{array}$ & $\begin{array}{l}30 \\
\text { days }\end{array}$ & $24 \mathrm{hrs}$ & 7 & None & None & 78 \\
\hline 4 & 20 & $\mathrm{M}$ & Rt. & A & $\mathrm{CR}$ & $\begin{array}{l}7 \\
\text { months }\end{array}$ & $\begin{array}{l}14 \\
\text { days }\end{array}$ & $72 \mathrm{hrs}$ & 8 & None & None & 69 \\
\hline 5 & 22 & M & Lt. & $\mathrm{C}$ & $\mathrm{CR}$ & $\begin{array}{l}4 \\
\text { months }\end{array}$ & 7 days & $36 \mathrm{hrs}$ & 9 & None & None & 69 \\
\hline 6 & 21 & $\mathrm{M}$ & Rt. & $\mathrm{C}$ & OR & $\begin{array}{l}5 \\
\text { months }\end{array}$ & 1 days & $24 \mathrm{hrs}$ & 20 & None & $\begin{array}{l}\text { AVN femoral } \\
\text { head detected at } \\
30 \text { months post- } \\
\text { op with } \\
\text { secondary } \\
\text { osteoarthritic } \\
\text { changes }\end{array}$ & 80 \\
\hline 7 & 22 & M & Rt. & $\mathrm{C}$ & OR & $\begin{array}{l}9 \\
\text { months }\end{array}$ & $\begin{array}{l}14 \\
\text { days }\end{array}$ & $72 \mathrm{hrs}$ & $\begin{array}{l}\begin{array}{l}\text { Non- } \\
\text { union }\end{array} \\
9 \\
\text { months } \\
\text { after } \\
\text { revision } \\
\text { surgery }\end{array}$ & $\begin{array}{l}\text { Exchange of } \\
\text { CCS done after } \\
4 \text { days of index } \\
\text { surgery } \\
\text { Revision } \\
\text { surgery with } \\
\text { fibular strut } \\
\text { grafting after } \\
14 \text { months for } \\
\text { non-union }\end{array}$ & None & 76 \\
\hline 8 & 22 & M & Rt. & $\mathrm{C}$ & OR & 4 months & $\begin{array}{l}25 \\
\text { days }\end{array}$ & $72 \mathrm{hrs}$ & $\begin{array}{l}\text { Infecte } \\
\mathrm{d} \text { Non- } \\
\text { union at } \\
3 \\
\text { months }\end{array}$ & $\begin{array}{l}\text { Exchange of } \\
\text { CCS done after } \\
1 \text { month } \\
\text { Serial } \\
\text { debridement \& } \\
\text { implant } \\
\text { removal } \\
\text { performed after } \\
5 \text { months }\end{array}$ & $\begin{array}{l}\text { Infected non- } \\
\text { union }\end{array}$ & $\begin{array}{l}6 \\
\text { Discharg } \\
\text { ed on } \\
\text { medical } \\
\text { grounds }\end{array}$ \\
\hline 9 & 19 & $\mathrm{~F}$ & Lt. & $\mathrm{C}$ & OR & 5 months & 2 days & $48 \mathrm{hrs}$ & 9 & None & None & 70 \\
\hline
\end{tabular}




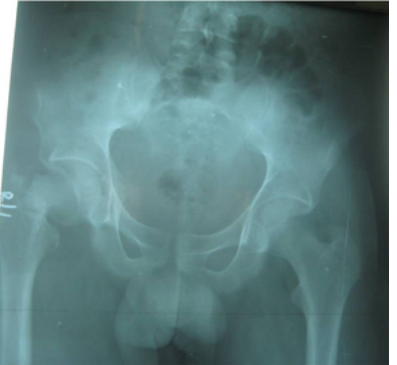

Figure 1. Displaced stress fracture of neck of femur

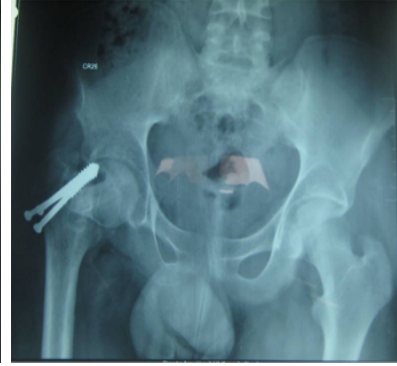

Figure 2. Post-operative case of stress fracture of neck of femur with failure of fixation presented at three months

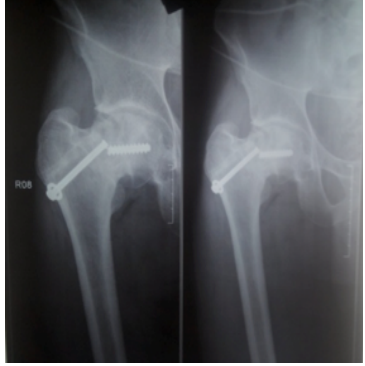

Figure 3. Non-union with broken cannulated cancellous screw at 9 months

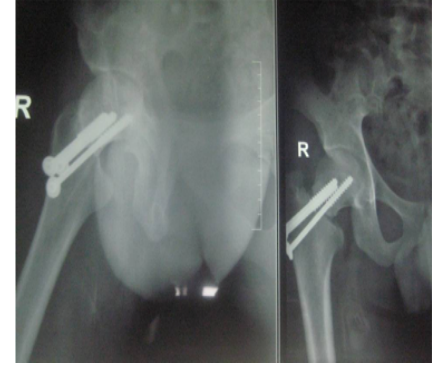

Figure 4. Infected nonunion with short superior cannulated cancellous screws

Open reduction and lag screw fixation were done in four cases out of which one case $(25 \%)$ had nonunion. For this case, revision surgery with fibular strut grafting was performed after 14 months. Fracture united nine months after the revision surgery. Surgical procedure was carried out at a mean duration of 52 hours (range, 24-72 hrs) after the injury. All patients had vague complaints of pain around the hip for an average duration of 12.4 days (range, 1-30 days) prior to sustaining FNSF. Six cases had clinical and radiological union at a mean duration of 9.8 months (range, 6-20 months) after the index surgical treatment.

Second surgical procedure to exchange cancellous lag screw was performed in two cases because the threads of the CCS had not crossed the fracture site. In these two cases, there were complications of non-union in one and infected non-union in the other

Two (22.2\%) patients developed non-union of the fracture. In these cases, one patient had union of the

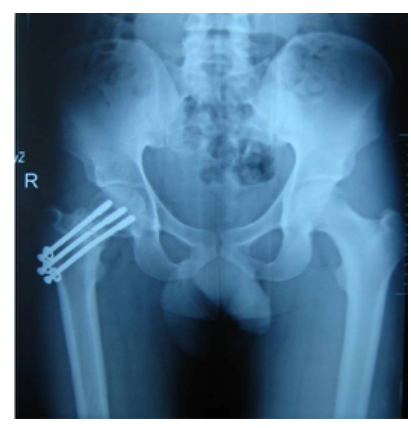

Figure 5. Non-union of stress fracture of neck of femur at 14 months

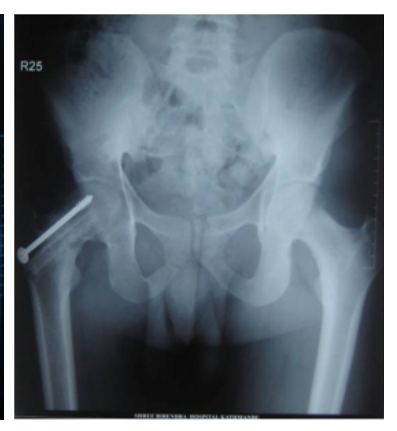

Figure 6. United fracture of neck of femur 9 months after osteosynthesis with fibular autograft fracture nine months after the second surgery using fibular strut graft whereas another failed to unite even after the second surgery using fibular strut graft. One $(11.1 \%)$ patient developed postoperative infection with non-union. He was later discharged from the service on medical grounds and could not be followed-up. One (11.1\%) patient developed AVN of femoral head at 30 months after the surgical treatment.

Mean Harris hip score at six month follow-up was 78.3 (range, 50-100) and at final follow-up was 93.8 (range, 69-100). At final follow-up, eight patients were still serving in the military with excellent functional outcome in six patients and poor functional outcome in two patients.

\section{DISCUSSION}

FNSF represents $3.5 \%$ to $8 \%$ of all stress fractures seen in military recruits. ${ }^{12,13}$ In our study, nine cases of FNSF occurred within one year out of which eight cases $(88.8 \%)$ were displaced type.

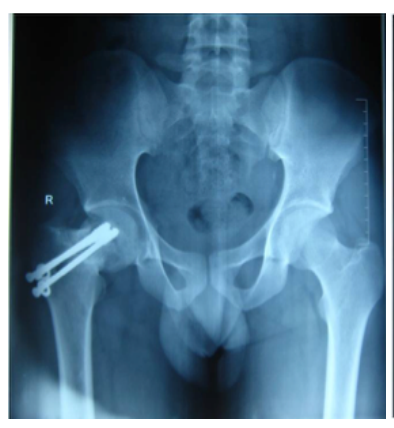

Figure 7. Varus

malunion of stress fracture of neck of femur

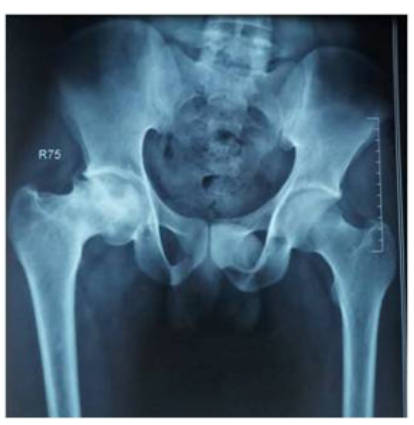

Figure 8. Avascular necrosis of femoral head with secondary osteoarthritic changes detected at two and half 
Table 2. Harris Hip Score patient data

\begin{tabular}{|l|rr}
\hline \multicolumn{2}{|c}{ Case No. $\begin{array}{c}\text { HHS at six } \\
\text { months }\end{array}$} \\
\hline 1 & 100 & 100 \\
2 & 60 & 69 \\
follow-up & 100 \\
3 & 97 & 100 \\
4 & 78 & 100 \\
5 & 80 & 82 \\
6 & 73 & 100 \\
7 & 84 & - \\
8 & 50 & 100 \\
9 & 83 &
\end{tabular}

This represents a very high rate of FNSF in Nepalese military recruits. A retrospective study done in our own centre by Joshi A et al. in 2009 showed that 24 cases of FNSF occurred in four years period. Of those included in the study, eight cases out of sixteen $(50 \%)$ had displaced FNSF. ${ }^{14}$ The incidence of displaced FNSF varied from 1.8 per 10,000 in British Army recruits to 9.3 per 10,000 in British Royal Marine recruits. ${ }^{15}$

In our study complications developed in four cases out of nine $(44.4 \%)$. This rate of complication is low compared to the study of Joshi A et al. ${ }^{14}$, in which complications developed in five cases out of eight $(62.5 \%)$ but high compared to the study of Lee $\mathrm{CH}$ et al. ${ }^{16}$, in which complications developed in ten cases out of forty two $(23.8 \%)$. This may be because of the inherent complications of displaced fracture neck of femur and steep learning curve required to achieve anatomical reduction of the fracture with proper orientation of cancellous screws in order to achieve stable inter-fragmentary compression.

In our study, proportion of non-union as a complication was seen in three case out of nine (33.3\%), where as AVN of femoral head was seen in one case out of nine $(11.1 \%)$. In a study done in our own centre by Joshi A et al. ${ }^{14}$, the proportion of AVN of femoral head was seen in three cases out of eleven $(27.2 \%)$, where as, two cases out of eleven $(18.1 \%)$ had non-union. This high rate of non-union may be because of non-anatomical reduction by closed reduction method and technical difficulty of performing the surgery using portable X-ray. Exchange of cancellous lag screws had to be performed in two cases out of which one case later developed non-union and the other case developed infected non-union.
In a study by Visuri $\mathrm{T}$ et al. ${ }^{18}$, twelve displaced FNSF treated by various methods were followed up for a mean period of four years. Sliding hip compression screw was used in ten cases, Jewett nail in one and $130^{\circ}$ angled AO-plate in one case. AVN of femoral head developed in five cases out of twelve (41.6\%) and non-union combined with AVN of femoral head in three cases out of twelve (25\%). This shows that morbidity of displaced FNSF is very high due to non-union, AVN of femoral head and secondary osteoarthritis in relatively young age and preventive measures are recommended.

In a study by Gautam VK et al. ${ }^{19}, 25$ patients with displaced fracture of neck of femur were operated on an ordinary operating table, using a WatsonJones approach similar to our study. Open reduction of the fracture was done through anterior capsular incision and fixed with $6.5 \mathrm{~mm}$ cancellous screws. Average interval between injury and operation was 6.6 days and average follow-up period was 32 months. They had early postoperative complications of superficial wound infection in one case $(4 \%)$ and fixation with too long screws in three cases $(12 \%)$. AVN of femoral head developed in three cases (12\%) detected between 12 and 18 months after the operation.

The incidence of AVN of femoral head in displaced FNSF ranges from $30 \%{ }^{20}$ to $42 \% .{ }^{18,20}$ In our study, AVN of femoral head developed in one case (11.1\%) after 30 months of index surgery. In Lee et al's series of 42 displaced FNSF, seven out of 25 patients $(28 \%)$ treated with multiple cancellous screws developed AVN of femoral head at a mean follow-up period of 5.6 years. ${ }^{17}$ This shows that long term follow-up of surgically treated FNSF is required to detect $\mathrm{AVN}$ of femoral head.

The mean delay until surgery in our series was 52 hours. This is because of the time taken for preoperative evaluation and preparation for surgery. In their cohort of six displaced FNSF operated within 12 hours, Evans et al. had no cases of AVN of femoral head. ${ }^{21}$

In our study, mean HHS at six months was 78.3 and at final follow-up was 93.8. Only one patient $(11.1 \%)$ was discharged on medical grounds and remaining eight patients were still serving in the military. In contrast, displaced FNSF have been associated with military discharge rate ranges from $40 \%$ to $100 \% .^{13,14}$ In our study six patients had 
excellent functional outcome. However, two patients had poor functional outcome with secondary osteoarthritis.

The limitation of this study is that it is a single centre study with a small sample size. One patient had short follow-up of only six months. The strengths of this study are surgical procedures were performed by the same surgical team using the same implants and the patients were followed-up for a relatively long period of over six years duration. To the best of our knowledge, this is the first study to assess the functional outcome of surgical treatment of stress fracture of neck of femur in Nepalese military.

\section{CONCLUSIONS}

Successful surgical treatment of stress fracture of neck of femur requires anatomical reduction and stable inter-fragmentary compression with lag screws. There is a high morbidity associated with this injury and long term follow-up is required to detect avascular necrosis of femoral head.

To cite this article: Magar SR, Chand P, Thapa BB, Sinha R, Shah RP, Maharjan D, et al. Outcome of surgical treatment of stress fracture neck of femur in military recruits. MJSBH. 2020;19(2):90-6.

Conflict of Interest: None declared

\section{REFERENCES}

1. Stoneham MD, Morgan NV. Stress fractures of the hip in Royal Marine recruits under training: A retrospective analysis. Br J Sports Med. 1991;25(3):145-8. DOI: http://dx.doi.org/10.1136/bjsm.25.3.145

2. Jacobs JM, Cameron KL, Bojescul JA. Lower extremity stress fractures in the military. Clin Sports Med. 2014;33: 591-613. DOI: http://dx.doi.org/10.1016/j.csm.2014.06.002

3. Fullerton LR, Jr, Snowdy HA. Femoral neck stress fractures. Am J Sports Med. 1988;16:365-77. DOI: https:// doi.org/10.1016/j.csm.2005.08.003

4. Shin AY, Gillingham BL. Fatigue fractures of the femoral neck in atheletes. J Am Acad Orthop Surg. 1997;5(6): 293-302. DOI: https://doi.org/10.5435/00124635-199711000-00001

5. Canale ST, Beaty JH. Campbell's operative orthopaedics. 11th ed. Philadelphia: Elsevier; 2008.; pp. $3271-83$.

6. Egol KA, Koval K, Kummer F, Frankel VH. Stress fractures of the femoral neck. Clin Orthop Relat Res. 1998; (348):72-8. PMID:9553536

7. Roertson GA, Wood AM. Femoral neck stress fractures in sport: a current concepts review. Sports Med Int Open. 2017;1:E58-E68. DOI: http://dx.doiorg/10.1055/s-0043-103946

8. Meyers MH, Harvey JP, Jr, Moore TM. Treatment of displaced subcapital and transcervical fractures of the femoral neck by muscle pedicle bone graft and internal fixation, a preliminary report on one hundred and fifty cases. J Bone Joint Surg Am. 1973;55:257-74. PMID: 4572222

9. Garden RS: Reduction and fixation of subcapital fractures of the femur. Orthop Clin North Am. 1974;5:683. PMID: 4606995

10. Watson-Jones R: Fractures of the neck of the femur. Br J Surg. 1936;23:787. DOI: https://doi.org/10.1002/bjs. 1800239213

11. Nagi ON, Gautam VK, Marya SK. Treatment of femoral neck fractures with a cancellous screw and fibular graft. J Bone Joint Surg Br. 1986;68-B:387-91. DOI: https://doi.org/10.1302/0301-620X.68B3.3733802

12. Harris WH. Traumatic arthritis of the hip after dislocation and acetabular fractures: treatment by mold arthroplasty: an end-result study using a new method of result evaluation. J Bone Joint Surg Am. 1969;51(A):737-55. PMID: 5783851

13. Pihlajamäki HK, Ruohola JP, Kiuro MJ, Visuri TI. Displaced femoral neck fatigue fractures in military recruits. J Bone Joint Surg Am. 2006;88(9):1989-97. DOI: https://doi.org/10.2106/JBJS.E.00505

14. Talbot JC, Cox G, Townend M, Langham M, Parker PJ. Femoral neck stress fractures in military personnel-a case series. J R Army Med Corps. 2008;154(1):47-50. DOI: http://dx.doi.org/10.1136/jramc-154-01-13 
15. Joshi A, KC BR, Shah BC, Chand P, Thapa BB, Kayastha N. Femoral neck stress fractures in military personnel. J Nepal Med Assoc. 2009;48(174):99-102. PMID: 20387346

16. Pihlajamäki HK, Ruohola JP, Weckström M, Kiuru MJ, Visuri TI. Long-term outcome of undisplaced fatigue fractures of the femoral neck in young male adults. J Bone Joint Surg Br. 2006;88-B:1574-9. DOI: https://doi.org/ 10.1302/0301-620X.88B12.17996

17. Lee CH, Huang GS, Chao KH, Jean JL, Wu SS. Surgical treatment of displaced stress fractures of the femoral neck in military recruits: a report of 42 cases. Arch Orthop Trauma Surg. 2003;123(10):527-33. DOI: https://doi.org/ $10.1007 / \mathrm{s} 00402-003-0579-8$

18. Visuri T, Vara A, Meurman K. Displaced stress fractures of the femoral neck in young male adults: a report of twelve operative cases. J Orthop Trauma. 1988;28(11):1562-9. DOI: https://doi.org/ 10.1097/00005373-198811000-00007

19. Gautam VK, Anand S, Dhaon BK. Management of displaced femoral neck fractures in young adults (a group at risk). Injury. 1998;9:15-8. DOI: https://doi.org/10.1177\%2F036354658801600411

20. Johansson C, Ekenman I, Tornkvist H, Eriksson E. Stress fractures of the femoral neck in atheletes. The consequence of a delay in diagnosis. Am J Sports Med. 1990;18(5):524-8. DOI: https://doi.org/ $10.1177 \% 2 \mathrm{~F} 036354659001800514$

21. Evans JT, Guyver PM, Kassam AM, Hubble MJW. Displaced femoral neck stress fractures in royal marine recruitsmanagement and results of operative treatment. J Roy Nav Med Serv. 2012;98(2):3-5. PMID: 22970637 